\title{
The Role of the Government's Mass Mobilization in Stabilizing the People's Situation in the Districts of Ho Chi Minh City Today
}

\author{
Ngoc Loi Pham*, Phuong Khanh Vo \\ Ho Chi Minh City Cadre Academy, Ho Chi Minh City, Vietnam
}

*Corresponding Author: Ngoc Loi Pham, Ho Chi Minh City Cadre Academy, Ho Chi Minh City, Vietnam

\begin{abstract}
This study aims to explore how the government's mass mobilization affects the economic, cultural, and social situation of the people in the districts of Ho Chi Minh city. The author used the research methodology of Marxism-Leninism, Ho Chi Minh's ideology, the Party's lines and views, and the State's policies to study about the government's mass mobilization work. In addition to the initial information collection method, in this study, we also used a series of other methods in scientific research such as analysis and synthesis, interpretation and inductive, generalization, logic, history, and comparison. In particular, the author used both quantitative and qualitative research to investigate and survey to analyze the people's situation and the effectiveness of the mass mobilization of the district government in Ho Chi Minh City today.
\end{abstract}

Keywords: the government's mass mobilization, stabilization, the people's situation.

\section{INTRODUCTION}

Ho Chi Minh City (also known as Saigon) is the largest city in Vietnam in terms of population and urbanization. This is also an economic, political, cultural, and educational center of Vietnam. Located in the area between the Southeast and the South West, the city currently has 16 districts, 1 city, and 5 districts, with a total area of 2,061 $\mathrm{km}^{2}$. According to the official census as of April 1, 2009, the city's population is $7,162,864$ (accounting for $8.34 \%$ of Vietnam's population), the average population density is 3,419 people/ $\mathrm{km}^{2}$. By 2019 , the city's population has increased to $8,993,082$ people and it is also the place with the highest population density in Vietnam [1]

Research on the situation of the people and their frustrations in the districts of Ho Chi Minh City help the mobilization work of the authorities in the districts achieve successful objectives, contributing to the development and improving the effectiveness and efficiency of state management, maintaining socio-political stability, proactively and actively integrating into the world, improving the quality of growth and competitiveness of the city's economy, linking economic growth with cultural development, realizing social progress, equity, protecting the environment, improving social welfare and quality of life for the people of the districts in particular and the whole city in general. Researching on the situation of the people in districts, specifically on quantity, structure, and qualifications, political ideology, economic development, material and spiritual life of the people find out the pressing, social problems posed for the district authorities that need to be resolved in the current districts

\section{LITERATURE REVIEW}

In the work of Mass mobilization (Dan Van) written on October 15, 1949, President Ho Chi Minh introduced the concept "Mass mobilization". "Mass mobilization" is to mobilize every capability of each person without leaving anyone behind, to create the all-people force to execute the work that should be done or was entrusted by the government and the unions" [2].

Applying Ho Chi Minh's ideology to the current innovation cause, it can be understood that mass mobilization work includes propaganda, advocacy, education, and persuading the people to well implement guidelines of the Party, policies, and laws of the state. It aims to gather and organize the people to participate in revolutionary movements to build a rich society, a strong country, with democracy, justice, and civilization. 
Government's mobilization is all activities of the Party and the government, organizations in the political system under the leadership of the Party to propagate, educate, mobilize, persuade and organize all the people to well implement the Party's undertakings and guidelines, the State's policies and laws, bringing into play the people's role and great potentials in the cause of national construction and defense, successfully implementing the goals, ideal of the Party. The resolution of the 12th National Congress of the Party has determined to ensure that the people can participate in all stages of the decision-making process related to their interests and lives. They can raise their ideas, participate in discussions, debate to monitor the implementation process.

\section{RESULTS AND DISCUSSION}

\subsection{The role of mass mobilization work in promoting the role of the People in the districts of Ho Chi Minh City.}

The revolution is not the work of an individual, a group of people, but the work of the entire people. The importance of mass mobilization work has been proved by the historical practice of the Vietnamese revolution. In the infancy of the revolution, most of the Party's cadres and members were close to the people. In his life, Lenin once warned of two risks of the ruling Communist Party, which were mistakes in the way and remaining aloof from the masses. Mass mobilization work contributes to strengthening the close relationship between the Party and the people. The 6th National Congress of the Party gave 4 profound lessons, of which, the first lesson was "in all its activities, the Party must grasp the idea of "taking the people as the root". The 10th National Congress of the Party also affirmed: "The trust, support, and help of the people are the source of strength, the cause of all victories and the Party's valuable asset [3]. The 11th National Congress of the Party summarized 5 great lessons, of which the second one continued to affirm: The cause of the revolution is of the people, by the people, and for the people. It is the people that make the innovation victories.

The government's mass mobilization plays an important part in enlightening, gathering, and attracting the masses of people into a great force and power to realize the goals of the country. Currently, the role of mass mobilization in the development of people's lives in the districts of Ho Chi Minh City is shown as follows:

\section{Regarding quantity, structure, and qualifications}

The total population of the five districts is currently 1,986,000. Binh Chanh district has 705,000 people, accounting for $35.5 \%$, the highest rate compared to the population of 5 districts, then respectively to Hoc Mon, $\mathrm{Cu}$ Chi, Nha Be and the lowest is Can Gio district with 71,000, accounting for $3.6 \%$ of the population of 5 districts. However, the population density of Hoc Mon district is the highest at 4972.5 people / $\mathrm{km} 2$, the lowest is Can Gio at 100.82 people / $\mathrm{km} 2$ compared to the other districts of Ho Chi Minh City

Table1. Area, population, population density of districts in Ho Chi Minh City in 2019

\begin{tabular}{|ll|l|l|l|}
\hline \multicolumn{2}{|l|}{ Name of districts } & Area $\left(\mathbf{K m}^{2}\right)$ & Population (person) & Population density (person/km ${ }^{2}$ ) \\
\hline Total & $\mathbf{1 6 0 1 . 0 0}$ & 1986000 & 1240.48 \\
\hline 1. & Cu Chi & 434.50 & 462000 & 1063.29 \\
\hline 2. & Hoc Mon & 109.18 & 542000 & 4964.29 \\
\hline 3. & Binh Chanh & 252.69 & 705000 & 2789.98 \\
\hline 4. & Nha Be & 100.41 & 206000 & 2051.59 \\
\hline $5 . \quad$ Can Gio & 704.22 & 71000 & 100.82 \\
\hline
\end{tabular}

The level of education has been improving in the districts of Ho Chi Minh City. $92.9 \%$ of the population of high school age are currently attending school and the literacy rate of the population aged 15 and over accounts for $99 \%$. The gap between men and women in literacy rates has narrowed significantly after 20 years, and there is almost no gender inequality in education. Currently, the working-age population of the 5 districts also in the labor supply chain of the city is generally considered to be relatively good. The professional qualifications of the workforce are increasing day by day, and the trained workers have partly met the requirements of enterprises and the labor market. The technical workforce has increased in both quantity and quality. The quality of labor is assessed by employers to be improved to meet the requirements of industrialization, modernization, and integration, which are shown in many criteria. Regarding health: the proportion of enterprises that 
said that the working health had been improved well accounted for $63.33 \%$ of the total number of surveyed enterprises; in terms of professional ethics: enterprises assessing the good level of labor, accounting for $47.23 \%$; in terms of expertise, techniques to meet the job: enterprises rated good level accounting for $48.20 \%$; in terms of work experience: enterprises evaluating the work experience of concentrated workers at fair level accounting for $48.90 \%$, professional skills accounting for $49.37 \%$, and soft skills accounting for $47.12 \%$.

The number of residents in the districts of Ho Chi Minh City working in the Party, State, Fatherland Front and mass organizations, state enterprises, and private sector accounts for a large proportion; the population who is retired according to the Labor Law regime also accounts for a large proportion compared to the other major cities in the whole country.

\section{Regarding political ideology}

Well implementing the guidelines on improving political ideology for the people, contributing to promoting democracy at the grassroots level, the district party committee under the Party Committee of Ho Chi Minh City has directed the coordination between the Fatherland Front, mass organizations and the government have well implemented the government's mass mobilization in implementing the Party and State's undertakings and policies, economic, cultural, social, security and defense goals at the grassroots level, to guide and supervise the people's self-governing activities, and to create favorable conditions for the people and enterprises to do business according to the law.

The document of the 11th Congress of the Party Committee of Ho Chi Minh City in term 2020 - 2025 affirms: "Enhance the responsibility to set an example and leadership capacity of the Party Committee to be worthy of the trust of the people, ensure defense - security, fast and sustainable development for the whole country, for the whole country, for the happiness of the people." [4]

Under the leadership of the city's Party Committee and Party Committees at all levels, the people of the districts have been aware of and have high political determination in implementing the process of innovation, deepening international economic integration, taking advantage of opportunities and favorable conditions of the world's positive trends to promote internal resources, taking advantage of external resources - capital resources, new technologies, experience in management and market expansion - to serve the city's industrialization and modernization.

Patriotic emulation, creative labor emulation, administrative reform associated with the Creative Award response, and the campaign "Ho Chi Minh City's people do not litter the roads and canals for a clean city and reduced flooding have been promoted and have aroused the spirit of emulation, creativity and attracted a large number of people to respond, practically contributing to promoting socio-economic development and political ideology of the districts' people in the City [5].

In general, the majority of residents and families in the districts believe in the leadership of the Party, the management and administration of the State, but directly from the party committee, local authorities, actively participating in building the Party, government, and mass organizations; upholding the spirit of revolutionary vigilance, actively fighting against the distorted and destructive rhetoric of hostile forces.

At the same time, the people actively participate in economic, political, cultural, social, and security activities organized by the authorities and mass organizations. The people of the districts in particular and the city, in general, are proud of the revolutionary tradition and heroic history of the city, clearly shown in the comments on the draft documents of the National Party Congress, draft documents of the Party congress at all levels of the City; give comments on draft legal documents, guidelines and policies of the city, contributing to the development of regulations on activities in residential areas.

\section{In terms of economic development, material and spiritual life}

The material and spiritual life of the majority of the people in the urban districts of the city since 2015 has changed a lot, and many families have a good living standard. The vast majority of the people in the districts have an educational level of secondary school or above. Most families have a stable and gradually improved life.

Cu Chi District: In the period (2015-2020), the life of the District's people has had many significant changes. The programs and plans have focused on a better life for the people. The program of 
improving the quality of new rural construction is focused on implementation. The State management of the construction order is focused on implementing strictly with many solutions, and construction cases are not allowed to decrease. Environmental protection has created a positive change in people's awareness and action. Areas with environmental pollution have been controlled and addressed promptly. The implementation of many different solutions has helped the district program of sustainable poverty reduction in the period 2016 - 2020 achieve high efficiency. From 2016 to 2018, the district reduced the poverty rate from $7.66 \%$ at the beginning of 2016 to $0.36 \%$ by the end of 2018, the rate decreased by $7.3 \%$. Currently, the whole district has 374 poor households. Near-poor households actively rose to escape poverty, over the past 3 years, near-poor households in the whole district have reduced more than 10,000 households, currently there are only 2,955 near-poor households. Up to now, $\mathrm{Cu} \mathrm{Chi}$ district has completed the poverty reduction program for the period 2016 - 2020. The district has supported learning costs for more than 8,200 cases, granted 76,948 health insurance cards to poor and near-poor households, and built 85 compassion houses for poor households [6]

Binh Chanh district: In the period (2015 - 2020), there were many significant changes in the people's life. The total production value (at constant 2015 prices) was $46,921.9$ billion VND, reaching $100 \%$ of the plan, which increased by $20.5 \%$ compared to the same period in 2020 . The situation of political security, social order, and safety in the district is stable. State budget revenue reached 1,941,199 billion Dong, increased by $7.77 \%$ compared with the plan target. The investment in the development of technical and social infrastructures associated with the rural construction program has been focused on implementation. The work of land management, construction has many positive changes, reducing $54.59 \%$ of the works that violate the construction order. Sustainable poverty reduction was well organized in the district, reducing the number of poor and near-poor households through support solutions. By the end of 2018, the whole district currently has 486 poor households, accounting for $0.31 \%$ and 2,727 near-poor households representing $1.75 \%$ of the total number of households in the district. At the same time, in 5 years, the budget has completed and put into use 438 projects, meeting the needs of the people in the district. The infrastructure system of the district has been invested and improved remarkably. Up to now, the whole district has $100 \%$ of rural roads concreted and asphalted according to the new rural standards. Besides, education and health have been invested for development; social security work have ensured to promptly and fully implemented; political security, social safety, and order have been maintained [7].

Hoc Mon district: In the period 2015 - 2020 with the solidarity and efforts to overcome difficulties of the entire Party Committee, authorities, and people, Hoc Mon district today has been gradually changing appearances. Technical and social infrastructure system serving the material and spiritual life of the people in the district has been increasingly invested, upgraded, and expanded; economic growth rate reached $15.84 \%$; the State management over land and construction order has been step by step reorganized and put into order; many schools and traffic works have been built to meet the needs of travel and learning for the people. Also, cultural, art, and sports activities to serve the entertainment and practice needs of the people have been regularly organized; the people's material and spiritual life is constantly being raised. The district's political security, social order, and safety continued to be maintained. In 2019, Hoc Mon district's socio-economy continued to be stable. Specifically, the tradeservice industry is well developed; service revenue is estimated at over 118,998 billion dong, reaching $99.58 \%$ of the year plan and up $21.06 \%$ over the same period in 2015. Along with the economic development, the national target program on building new rural areas in the district continued to achieve important results. Up to now, on average, communes have reached 18.6 criteria, district reached 9 / 9 criteria. The people's health care, education, socio-culture were paid attention to promptly and in the right direction; the political security situation was maintained stable [8].

\subsection{The assessment of the people, public servants and officials in the districts of Ho Chi Minh city.}

Socio-economic, political, cultural, and social development of Ho Chi Minh City's districts for the five years 2016-2020 takes place in the context of the region and the world having both advantages and disadvantages. In particular, in the last year of the 5-year plan period 2016 - 2020, the Covid-19 pandemic, unprecedented for decades globally, has a very serious impact; the world economy falls into a recession. The consequences may last for many years. However, there are many changes in the situation of people in the districts of Ho Chi Minh City, as follows: 
The Role of the Government's Mass Mobilization in Stabilizing the People's Situation in the Districts of Ho Chi Minh City Today

Chart2.1. Evaluation of economic, political, cultural, and social activities compared to the previous 5 years in the districts of Ho Chi Minh city:

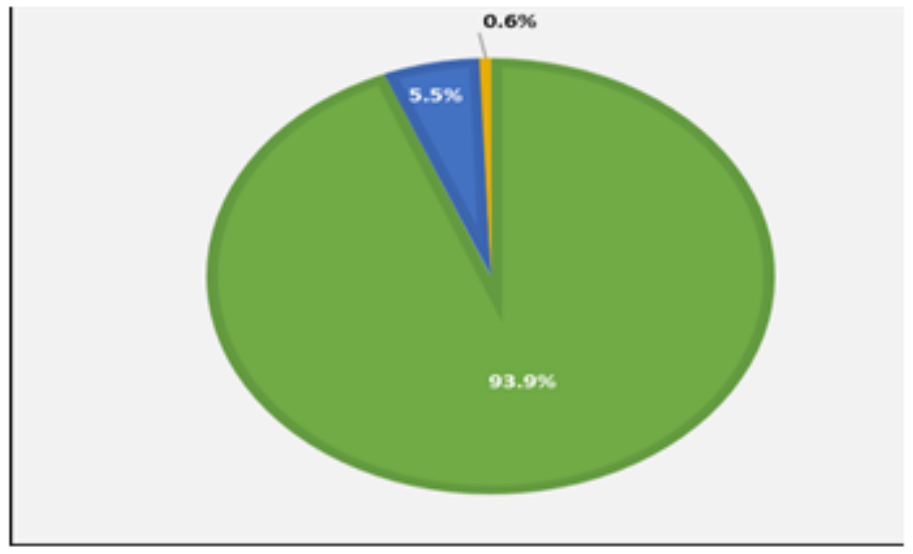

\section{Better than before}

Remain the same

worse than before

Figure 2.1 shows according to the assessment of the people and cadres, civil servants, and public employees, there are many changes in the economic, political, cultural, and social activities in the districts of Ho Chi Minh City compared to the previous five years. The proportion of the people, civil servants, and public employees said that it is better than before is almost $93.9 \%$ compared with indicators 1 and 2 .

Considering social groups, it shows that people's perceptions also have many different changes in economic, political, cultural, and social activities compared to 5 years ago in the districts of Ho Chi Minh City today.

Table2.2. Evaluation of economic, political, cultural and social activities of districts in Ho Chi Minh city compared to 5 years ago

\begin{tabular}{|c|c|c|c|c|c|c|c|c|c|c|c|c|}
\hline \multirow{3}{*}{ Evaluation } & \multicolumn{12}{|c|}{ District } \\
\hline & \multicolumn{2}{|c|}{$\mathrm{Cu}$ Chi } & \multicolumn{2}{|c|}{ Hoc Mon } & \multicolumn{2}{|c|}{ Can Gio } & \multicolumn{2}{|c|}{ Nha Be } & \multicolumn{2}{|c|}{ Binh Chanh } & \multicolumn{2}{|c|}{ Total } \\
\hline & $\mathrm{N}$ & $\%$ & $\mathrm{~N}$ & $\%$ & $\mathrm{~N}$ & $\%$ & $\mathrm{~N}$ & $\%$ & $\mathrm{~N}$ & $\%$ & $\mathrm{~N}$ & $\%$ \\
\hline 1. Better than before & 87 & 92.6 & 94 & 94.9 & 94 & 94.0 & 94 & 94.0 & 93 & 93.9 & 462 & 93.9 \\
\hline 2. Remain the same & 7 & 7.4 & 5 & 5.1 & 6 & 6.0 & 6 & 6.0 & 3 & 3.0 & 27 & 5.5 \\
\hline $\begin{array}{l}\text { 3. Worse than } \\
\text { before }\end{array}$ & 0 & 0.0 & 0 & 0.0 & 0 & 0.0 & 0 & 0.0 & 3 & 3.0 & 3 & 0.6 \\
\hline Total & 94 & 100.0 & 99 & 100.0 & 100 & 100.0 & 100 & 100.0 & 99 & 100.0 & 492 & 100.0 \\
\hline
\end{tabular}

Regarding the group of districts in table 2.2, it shows that in indicator 1 , the people of all 5 districts have the same perception since the percentage shows no difference. However, in indicator 3 , it shows that 3.0\% of the people in Binh Chanh district think that it is worse than before.

Regarding the change compared to before, $\mathrm{Cu}$ Chi people said that nothing has changed, accounting for $7.4 \%$, this proportion is relatively high compared to other districts. The educational level group shows that the higher the educational level is, the more positive their assessment is. The majority of the group is the people with higher education levels $(98.1 \%)$

\subsection{Limitations}

Along with the achievements, there are pressing problems emerging among the people in the districts of Ho Chi Minh City that need to be addressed. The lives of most migrants into the city face many difficulties, deprivations, and declines, especially for employees, salaried workers and retirees, lonely and helpless people.

The situation of corruption, waste, bureaucracy, arrogance, authoritarianism, harassment on the part of public officials and civil servants has not been prevented or repelled, causing frustration among the people. Organized crime, robbery, theft, fraud, and "gangster" gangs are strongly active in some places; social evils are increasingly complicated, threatening people's lives. The awareness of abiding by the Traffic Law of many people is still very poor; traffic accidents increased, causing the people's worries. The rich and poor differentiation among the population has increased and tends to be further and further away. The environment is increasingly polluted. Recently, the rapid increase in 
The Role of the Government's Mass Mobilization in Stabilizing the People's Situation in the Districts of Ho Chi Minh City Today

commodity prices has made it difficult to meet the essential needs of people's lives, especially in education and medical examination and treatment.

Over the past few years, religions have adjusted, adapted, and expanded the forms of religious activities to attract non-believers. Some religious dignitaries have carried out activities that are not under the law, deceived, and incited a part of parishioners to oppose the government, badly affecting the Party committees and authorities in Ho Chi Minh City.

Table2.3. The pressing issues are emerging in the districts of Ho Chi Minh city.

\begin{tabular}{|c|c|c|}
\hline \multirow{2}{*}{ Pressing problems } & \multicolumn{2}{|c|}{ Total } \\
\hline & $\mathrm{N}$ & $\%$ \\
\hline 1. $\quad$ Prices increased & 324 & 65.9 \\
\hline 2. $\quad$ Salary and Income & 347 & 70.5 \\
\hline 3. $\quad$ Rich and poor disparity & 197 & 40.0 \\
\hline 4. $\quad$ Food safety & 344 & 69.9 \\
\hline 5. $\quad$ Urban inundation & 384 & 78.0 \\
\hline 6. $\quad$ Environmental pollution & 378 & 76.8 \\
\hline 7. $\quad$ Traffic accidents & 308 & 62.6 \\
\hline 8. $\quad$ Uncontrolled immigration & 224 & 45.5 \\
\hline 9. $\quad$ Moral degradation of a part of teachers & 168 & 34.1 \\
\hline 10. The moral deterioration of a part of cadres and party members & 237 & 48.2 \\
\hline 11. Compensation, clearance, resettlement issues & 216 & 43.9 \\
\hline 12. Natural disasters and epidemics & 217 & 44.1 \\
\hline 13. Corruption of a part of civil servants & 215 & 43.7 \\
\hline 14. The situation of solving complaints and denunciation of the people & 147 & 29.9 \\
\hline 15. Vaccination for children & 128 & 26.0 \\
\hline 16. Corruption and waste & 286 & 58.1 \\
\hline 17. Real estate procedures still have many shortcomings & 293 & 59.6 \\
\hline 18. Social evils and crime & 283 & 57.5 \\
\hline 19. Cultural products with bad contents circulate on the internet & 237 & 48.2 \\
\hline 20. Fees, charges and advocacy contribution in the neighborhood & 126 & 25.6 \\
\hline 21. Some religious dignitaries have not worked properly with the law & 97 & 19.7 \\
\hline Total & 492 & 100.0 \\
\hline
\end{tabular}

Table 2.3 shows that out of 21 indicators in urban districts, 9 pressing indicators emerged as big concerns in the districts of Ho Chi Minh city (indicators 1, 2, 4, 5, 6, 7, 16, 17, and 18). Presently, in indicator 5, urban flooding indicator, the people and officials think it is the most pressing issue, accounting for $78.0 \%$. It is followed by indicator 6, environmental pollution, representing $76.8 \%$. Food safety salary, income, rising prices, social evils, crime, and traffic accidents are also being paid attention to by the people, officials, and employees. The operation of religious issues has gone into order, operating by law accounts for $19.7 \%$. Vaccination for children has been well implemented in these areas, showing the attention of the government to future generations.

Many achievements have been made in resolving the problems of the people in the districts. Of which, the government's mass mobilization in these districts has been relatively well implemented. Is it because of improving the efficiency of the mobilization of the entire political system in the new situation, renewing the contents and modes of mass mobilization of the Front and mass organizations attractively and necessarily to improve the quality and efficiency of social supervision and criticism.

Chart2.2. Citizen's assessment of pressing issues resolved by district authorities in Ho Chi Minh City

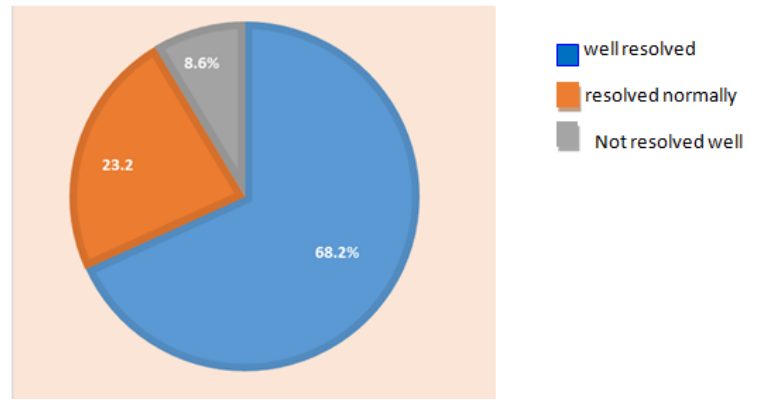


Figure 2.2 shows that the public's perception of pressing issues resolved by district authorities in Ho Chi Minh City is quite good. The pressing problem among the people is solved at a good level of $68.2 \%$, at the normal level of $23.2 \%$, and a low level of only $8.6 \%$.

This result shows that the districts have promoted the implementation of the government's mass mobilization and the democratic regulations at the grassroots level, focusing on promoting the people's ownership, implementing administrative procedures, preventing corruption, bureaucracy, corruption, waste, and increasing satisfaction of the people and businesses [9]

\section{CONCLUSION}

In conclusion, studying the role of the government's mass mobilization in stabilizing the current situation of the people in the districts of Ho Chi Minh City the author has found that it is the Party's leadership in mass mobilization in the new situation that has firmly consolidated the people's trust in the Party, strengthened national solidarity and the close relationship between the Party and people; gathered and mobilized the people to well implement the Party's undertakings and the State's policies and laws to build and defend the Fatherland, successfully carry out the industrialization and modernization of the country

1 / The role of the government's mass mobilization in stabilizing the current situation of the people in the districts of Ho Chi Minh City in terms of both quantity, structure, and level of people reaching universal and ideological qualifications, politics, economic development, material, and spiritual life are enhanced.

2 / The assessment of the people, cadres, civil servants, and public employees in the area shows that there have been positive changes in economic, political, cultural, and social activities compared to the previous 5 years. The assessment level of better than before accounts for $93.9 \%$.

3 / The study also pointed out some pressing issues emerging among the people in the districts of Ho Chi Minh City that need to be addressed. The lives of most migrants into the city face many difficulties, deprivations, and declines, especially for employees, salaried workers and retirees, lonely and helpless people. Corruption, wastefulness, bureaucracy, arrogance, authoritarianism, and harassment on the part of public officials and civil servants have not been prevented or repelled, causing frustration among the people.

\section{REFERENCES}

[1] Ho Chi Minh City Statistical Office, 2019

[2] Ho Chi Minh (2002). Complete Works. Vol.5. Hanoi: National Political Publishing House, p.698.

[3] Communist Party of Vietnam (2006). Document of the Tenth National Congress of Representatives. Hanoi: National Political Publishing House, p. 304.

[4] Ho Chi Minh City Party Committee (2020). Document of the $11^{\text {th }}$ Congress of the term $2020-2025$. Ho Chi Minh City General Publishing House, p. 22

[5] Ho Chi Minh City Party Committee (2020). Document of the 11th Congress of the term $2020-2025$. Ho Chi Minh City General Publishing House, p. 38

[6] Thu Ha (2020). Cu Chi basically complete the poverty reduction program period 2016 - 2020.

[7] Minh Anh (2020). Binh Chanh: Deploy 22 targets, 12 groups of tasks and solutions for socio-economic development in 2019.

[8] Minh Chau (2020). Hoc Mon district: Improving the quality of cultural, material and spiritual life for the people

[9] Tra Mi (2020). Strengthening dialogue and timely solving pressing problems among the people.

\section{AUTHORS' BIOGRAPHY}

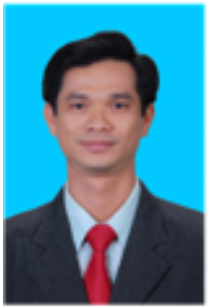

Ngoc Loi Pham, was previously a Deputy Secretary of Ho Chi Minh Communist Youth Union of District 12, Ho Chi Minh city. He was a chairman of the Youth Federation of District 12, Ho Chi Minh city. He also served as Vice-chairman of the People's Committee of Tan Thoi Nhat Ward, District 12, HCMC. He was a Deputy Director of the Political training center of District 12, Ho Chi Minh city. Now he works at Ho Chi Minh City Cadre Academy. He participated in many scientific research programs and projects at the academy, at ministerial-level and state-level. He 

Ho Chi Minh City Today

is also a lecturer at the academy and teaching at some universities in Vietnam.

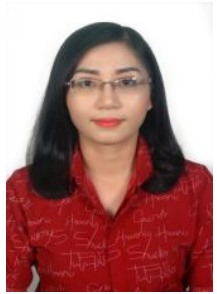

Phuong Khanh Vo, - Since January 2021 the Faculty of Public Relations and Social Work and the Faculty of the Party Building and Ho Chi Minh's Thought has merged into the Faculty of the Party Building - Ho Chi Minh City Cadre Academy. Now she is the secretary of the Faculty of the Party Building. She participated in the scientific research entitled "Output standards and develop output standards for social work training at Ho Chi Minh City Cadre Academy. She has achieved the title of "advanced labor"

Citation: Ngoc Loi Pham, Phuong Khanh Vo. "The Role of the Government's Mass Mobilization in Stabilizing the People's Situation in the Districts of Ho Chi Minh City Today" International Journal of Humanities Social Sciences and Education (IJHSSE), vol 8, no. 3, 2021, pp. 52-59. doi: https://doi.org/10.20431/2349-0381.0803005.

Copyright: () 2021 Authors. This is an open-access article distributed under the terms of the Creative Commons Attribution License, which permits unrestricted use, distribution, and reproduction in any medium, provided the original author and source are credited. 